\title{
Work Satisfaction Level of Private School Teachers in Yogyakarta Indonesia \\ DOI: https://doi.org/10.47175/rissj.v1i3.107
}

\section{| Enung Hasanah ${ }^{1}$ | Suyatno² Tugino $^{3}$ | Syahid Ali $^{4}$ |}

1,2,3,4 Educational

Management, Postgraduate

Program, Universitas Ahmad

Dahlan, Indonesia

enung.hasanah@mp.uad.ac.id

\begin{abstract}
This article aims to explore the level of teacher job satisfaction based on external factors, namely organizational policy factors, availability of promotion opportunities, and direct supervisor supervision. Participants in this study were 216 Muhammadiyah high school teachers in the Special Region of Yogyakarta, Indonesia, consisting of 79 men and 137 women. They become participants in this research voluntarily and are determined randomly. The data collection method was carried out by the teachers filling out the survey instruments deliberately. The data that has collected, then we process it using descriptive quantitative data processing techniques using SPSS 25. The results show that 1). The level of teacher job satisfaction from the aspect of organizational policy has a dominant distribution in the very high category (79.6\%), in the high category was $16.7 \%$, in the medium category was $3.2 \%$, while those in the low category were as much as $0.5 \%$; 2) The level of teacher job satisfaction regarding supervision was included in the very high category (89.8\%), in the high category was $18.3 \%$, in the medium category was $0.9 \%$, and in the low category were as much as $0.9 \%$; 3) The level of teacher satisfaction on aspects of promotion opportunity has a dominant distribution in the very high category (81\%), in the high category was $11.1 \%$, in the medium category was $7.4 \%$, and in the low category were as much us $0.5 \%$. These results indicate that the level of job satisfaction of teachers at SMA Muhammadiyah in Yogyakarta Indonesia is at a very high level of satisfaction. In the future, further research is needed regarding the level of teacher job satisfaction from various other factors, both internal and external, to obtain a more comprehensive picture.

KEYWORDS
\end{abstract}

Teacher; job satisfaction; organizational policy; supervision; promotion

\section{INTRODUCTION}

In the globalization era, there is a strong current of competition between organizations throughout the world. Every organization needs to create innovative ways of doing business to win the competition with competitors (Abbas \& Asgar, 2010. This condition also applies to schools as social and educational organizations that must be able to create creative ideas to build a positive school image, to gain public trust (Chu, EHS 2007; Karakus \& Savas, 2012). It needs to be realized by the managers of educational institutions

Educational managers need to understand that the quality of education outputs, such as the growth of positive student self-identity (Hasanah, et al., 2018; 2019) and the development of student's character and morals (Hasanah, 2019) became the benchmarks of community assessment of the image of schools in the 4.0 era, in addition to academic 
abilities. It shows that the challenges for schools become very sophisticated to be able to meet the expectations of the community.

Educational institutions (schools) need to be built into a learning organization so that schools can achieve scholarly output following the expectations of a dynamic society (Luhn, 2016). This condition is very important because schools must be able to solve problems that come from individuals and organizations themselves, and must be able to adapt to all changes. Therefore, school managers need to have an adequate body of knowledge about various aspects of school organization, adhere to professional ethics and values, and oriented towards improving processes and results (Braitanu, 2015), one of which pays attention to the level of teacher job satisfaction.

In school organizations, the teacher is the most critical element because the teacher is the spearhead in the process of achieving school goals. School administrators and managers need to ensure teacher job satisfaction because although teacher performance influenced by many factors (KNigama \& Surulivel, 2018), teacher job satisfaction is the main factor that influences it (Baluyos, Rivera, \& Baluyos, 2019; Ram, 2013). Teacher job satisfaction is part of a professional identity that can increase teacher productivity and creativity (Sarwar \& Khalid, 2011). Teacher productivity and creativity directly serve to improve the ability of teachers to build effective teacher-student interactions (Hasanah, 2016), instill character in students (Wagner \& Ruch, 2015), also expand collaboration with peers (Hasanah, 2014). Several studies have shown that teachers who are satisfied with their careers to teaching more effectively (Collie, Shapka, \& Perry, 2012; Demirtaş, 2010; Griva, Panitsidou, \& Chostelidou, 2012). The statement is in line with the results of Inuwa's research (2015) that there is a positive relationship between job satisfaction, work attitude, and equity in the performance of employees of an organization. Therefore, managers of Educational Institutions/schools need to have a good understanding of the level of teacher job satisfaction to support effective organizational development planning (Azi, \& Augustine, 2016). This information needed by all school providers, including private school providers in Indonesia, such as Muhammadiyah. Research on teacher satisfaction in Yogyakarta conducted by Tentama (2015). The results of the study point to a significant relationship between teacher job satisfaction and the performance of PNS teachers. However, there is insufficient literature on the job satisfaction status of teachers in private schools in Indonesia, especially in terms of various external aspects. This study aims to explore the level of teacher job satisfaction of private high school of factors related to their work. With the revealed level of job satisfaction of teachers in Yogyakarta, it can become valuable information for managers and organizers of Education for planning the development of private school in Indonesia.

\section{LITERATURE REVIEW}

This study outlines the concepts and theories relevant to teacher job satisfaction. Also discussed are the factors that influence teacher job satisfaction, both external and internal factors. The literature review function is to provide direction for the research conducted. The study of this theory includes the concept of job satisfaction, content-based satisfaction theory, and the factors that influence the level of teacher job satisfaction. Besides, it complemented by studies of relevant research that reinforces the understanding that job satisfaction has a direct influence on teacher performance.

\section{The concept of job satisfaction}

Job satisfaction can interpret as a positive or pleasant emotional condition (Locke, 1976), which results from the assessment of one's work or work experience (Anderson, 2001). 
Anderson notes that the definition combines cognition (judgment) and influence (emotional state). Based on Anderson's opinion, that job satisfaction results from mutual influence between perception, thoughts, and feelings. Based on several ideas regarding job satisfaction, in this study, teacher job satisfaction is defined as the teacher's positive attitude about his work as a result of the assessment of work experience he experienced as a teacher. Job satisfaction is closely related to the paradigm of thinking possessed by someone regarding his work. A job condition can produce a level of job satisfaction for someone, while for others does not necessarily produce job satisfaction. According to Kreitner (2010), this happens because someone could be satisfied if employee satisfaction lies in the appreciation of things that are valuable to employees (Value attainment). On the other hand, some people judge that one's satisfaction with work is related to the talent and genetic factors of that person (genetic component). So an essential element of research satisfaction about job satisfaction is how researchers measure the level of job satisfaction and understanding why work is necessary (Essays, 2018).

Job satisfaction is a multidimensional phenomenon, therefore it is natural that many experts have different opinions in identifying various job satisfaction factors. Job satisfaction is a complex construct and influenced by work environment factors and individual disposition characteristics (Shajahan \& Shajahan, 2004). These factors have been arranged according to two dimensions, namely, extrinsic and intrinsic factors. School administrators need to keep in mind that extrinsic and intrinsic factors often work together to influence job satisfaction (Anastasiou \& Papakonstantinou, 2014; Buitendach \& De Witte, 2005).

\section{Extrinsic factors that affect the level of teacher job satisfaction}

There are three extrinsic factors identified in this study as very dominant factors towards the growth of teacher job satisfaction. Sources of external job satisfaction are determined by conditions that are beyond the control of the employee. In this study, the factors identified as having a strong influence on the level of job satisfaction of teachers include organizational policy, supervision, and promotion opportunities.

\section{Organizational Policy}

Organizational policies and administration related to organizational effectiveness and employee performance. Lack of clear rules tends to produce conflicts, power vacancies, and overlapping and duplication of efforts (Spector, 1985). Therefore, organizational policy and administration are focused on feeling about the adequacy or inadequacy of corporate management. This area includes having good/bad communication, having/lacking delegated authority, policies, procedures, and rules.

\section{Supervision}

Supervision in schools is a vital process and is a combination of activities related to teaching and improvement of teaching in schools. The supervisor's ability to provide emotional, technical support, and guidance with work-related tasks forms an important role related to job satisfaction (Cockcroft, 2001). Supervision significantly affects job satisfaction if supervisors are considered fair in conducting monitoring and evaluation (Robbins, 1998).

\section{Promotion Opportunities}

While several studies have investigated the determinants of job satisfaction, relatively little attention has paid to the role of promotion and promotion expectations. Tournament theory postulates that companies use the prospect of promotion as an incentive for workers to put in more significant effort. Research conducted by Kosteas that the approach is correct; there 
is a positive relationship between promotion and job satisfaction depends on the perception of equality by employees (Malik, Danish, \& Munir, 2012). However, the understanding of promotion is not the only factor that has a positive impact on job satisfaction (Kosteas, Vasilios. (2010). It is very likely that employees are satisfied with the company's promotion policies, but are not happy with the opportunities for promotion. It may also be that individuals consider promotional policies an organization is unfair. However, because they do not have the desire to be promoted, they may still be satisfied Estimating the effect of promotion and the expectation of promotion on job satisfaction helps us understand the importance of promotion as a mechanism for eliciting more considerable effort from workers. Leading to greater job satisfaction, even after controlling for wage increases and wage increases, supports the idea that workers value promotion itself, giving companies nonmoney tools to extract efforts and other positive behaviors from workers.

\section{RESEARCH METHODS}

This research uses IBM SPSS version 25 for analysis data, using both descriptive and inferential statistical analysis. Descriptive statistics used to identify teacher job satisfaction levels with certain aspects of work and overall job satisfaction. A comparison of ways between groups often made to determine whether there are differences among groups. For the comparison of job satisfaction groups and the inferential analysis that is used. The two methods that mostly used to compare the means of different groups are independent sample t-tests and one-way analysis of variance (ANOVA). ANOVA is used to check whether or not there are differences between the various groups determined by multiple categories, namely: gender, age, experience, qualifications, and academic rank. To test the difference is in the level of statistical significance, 0.05 used. Participants in this research were 216 Muhammadiyah high school teachers in DIY who filled in the questionnaire voluntarily

\section{RESULT AND DISCUSSION}

This section presents a description of the results of research in the form of data about the level of satisfaction based on 3 external aspects factors of work, namely: a) The level of job satisfaction is an aspect of organizational policy; b). Job satisfaction level of promotion aspects; c). Level of work satisfaction aspects of work supervision. Data on the job satisfaction level of Muhammadiyah DIY High School teachers was obtained through instruments in the form of a questionnaire with a Likert scale. In more detail, a description of the results of the study can be seen in the following explanation:

\section{Teacher job satisfaction level aspects of organizational policy}

Data regarding teacher satisfaction levels of organizational policy aspects received by participants were obtained using a closed questionnaire. In the instrument, participants were asked about how participants viewed the organization policy including clarity of rules in the school, consistency in the implementation of the rules, the treatment of principals for all teachers equally, and how to lead conducted by the principal that suited the school conditions. The total questions to measure the level of teacher satisfaction in organizational policy aspects are 4 items with 5 Likert scales. Criteria for measuring the level of job satisfaction of teachers in terms of work are determined as follows: 
Table 1. Criteria for the level of job satisfaction of teachers aspects of organizational policy

\begin{tabular}{|l|l|}
\hline Values & Criteria \\
\hline $0-5$ & Very Low \\
\hline $6-10$ & Low \\
\hline $11-15$ & Medium \\
\hline $16-20$ & High \\
\hline $21-25$ & Very High \\
\hline
\end{tabular}

Statistically the variable data of the teacher's job satisfaction level aspects of organizational policy as follows:

Table 2. Statistics on the level of job satisfaction of teachers about organizational policy

\begin{tabular}{|l|c|c||c|c|}
\hline & $\begin{array}{c}\text { At my school, } \\
\text { there are clear } \\
\text { school-based } \\
\text { rules and } \\
\text { regulations. }\end{array}$ & $\begin{array}{c}\text { The } \\
\text { implementation of } \\
\text { rules and regu- } \\
\text { lations at school } \\
\text { satisfies me. }\end{array}$ & $\begin{array}{c}\text { The prin- } \\
\text { cipal treats } \\
\text { all teachers } \\
\text { equally in the } \\
\text { school. }\end{array}$ & $\begin{array}{c}\text { The way the } \\
\text { headmaster } \\
\text { leads the } \\
\text { school } \\
\text { satisfies me. }\end{array}$ \\
\hline $\mathrm{N}$ & 216 & 216 & 216 & 216 \\
\hline Valid & 0 & 0 & 0 & 0 \\
\hline Mean & 4.72 & 4.58 & 4.75 & 4.59 \\
\hline Median & 5.00 & 5.00 & 5.00 & 5.00 \\
\hline Mode & 5 & 5 & 5 & 5 \\
\hline
\end{tabular}

The results of data analysis regarding the level of teacher job satisfaction aspects of organizational policy can be seen in the following table 3

Table 3. Level of teacher job satisfaction on aspects of organizational policy

\begin{tabular}{|l|l|c|c|c|c|}
\hline \multicolumn{2}{|c|}{} & Frequency & Percent & $\begin{array}{c}\text { Valid } \\
\text { Percent }\end{array}$ & $\begin{array}{c}\text { Cumulative } \\
\text { Percent }\end{array}$ \\
\hline \multirow{4}{*}{ Valid } & $5.00-8.00$ & 1 & .5 & .5 & .5 \\
\cline { 2 - 6 } & $9.00-12.00$ & 7 & 3.2 & 3.2 & 3.7 \\
\cline { 2 - 6 } & $13.00-16.00$ & 36 & 16.7 & 16.7 & 20.4 \\
\cline { 2 - 6 } & $17.00-20.00$ & 172 & 79.6 & 79.6 & 100.0 \\
\cline { 2 - 6 } & Total & 216 & 100.0 & 100.0 & \\
\hline
\end{tabular}

Based on table 3, the level of teacher satisfaction on aspects of organizational policy has a dominant distribution in the very high category (79.6\%). The level of job satisfaction of teachers in the high category was $16.7 \%$, the level of job satisfaction of teachers in the 
medium category was $3.2 \%$, while those in the low category were as much as $0.5 \%$. Data from table 26, if illustrated in the form of pie charts can be seen in Figure 7 below:

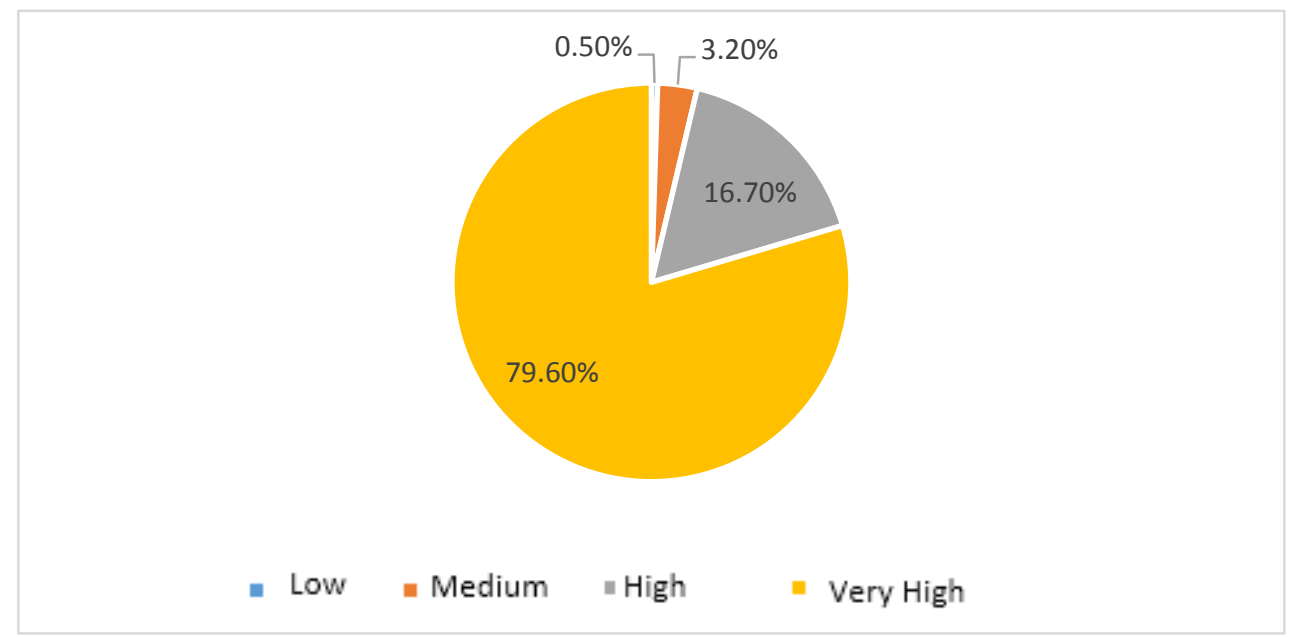

Figure 1. The level of teacher job satisfaction aspects of organizational policy

\section{Teacher Satisfaction Level About supervision}

Data regarding the teacher satisfaction level of supervision aspects were obtained using a closed questionnaire. In the instrument, participants were asked how participants assessed and felt about the implementation of direct supervision by principals on participants including: initiation of principals in improving academic achievement, principals' understanding of teachers' expectations, the principal's democratic attitude in conducting the supervision process, regular implementation of supervision by the principal, and the opportunities given by the principal to the teachers to attend various training. Total questions about the level of satisfaction regarding supervision are 5 items. Criteria for measuring the level of job satisfaction of teachers in terms of recognition of others is determined as follows:

Table 4. Criteria for the level of job satisfaction of teachers in supervision aspects

\begin{tabular}{|l|l|}
\hline Values & Criteria \\
\hline $0-5$ & Very Low \\
\hline $6-10$ & Low \\
\hline $11-15$ & Medium \\
\hline $16-20$ & High \\
\hline $21-25$ & Very High \\
\hline
\end{tabular}

Statistically the variable data of the teacher's job satisfaction level in supervision can be seen in table 5 below: 
Table 5. Statistics on teacher job satisfaction levels of supervision

\begin{tabular}{|l|c|c|c|c||c|}
\hline & $\begin{array}{c}\text { The } \\
\text { headmaster } \\
\text { always } \\
\text { proactively } \\
\text { initiated me to } \\
\text { discuss the } \\
\text { problem of } \\
\text { Students' } \\
\text { academic } \\
\text { achievement }\end{array}$ & $\begin{array}{c}\text { The } \\
\text { principal is } \\
\text { technically } \\
\text { a 'know- } \\
\text { how' to } \\
\text { Support } \\
\text { me. }\end{array}$ & $\begin{array}{c}\text { I am } \\
\text { supervised } \\
\text { by supe- } \\
\text { riors in a } \\
\text { Democratic } \\
\text { manner. }\end{array}$ & $\begin{array}{c}\text { The } \\
\text { principal } \\
\text { conducts } \\
\text { regular } \\
\text { academic } \\
\text { supervision. }\end{array}$ & $\begin{array}{c}\text { The } \\
\text { headmaster } \\
\text { provides an } \\
\text { opportunity } \\
\text { for me to } \\
\text { attend } \\
\text { Various } \\
\text { training. }\end{array}$ \\
\hline N & 216 & 216 & 216 & 216 & 216 \\
\hline Valid & 0 & 0 & 0 & 0 & 0 \\
\hline Mean & 4.69 & 4.64 & 4.78 & 4.63 & 4.85 \\
\hline Median & 5.00 & 5.00 & 5.00 & 5.00 & 5.00 \\
\hline Mode & 5 & 5 & 5 & 5 & 5 \\
\hline
\end{tabular}

The distribution of teacher job satisfaction levels on the supervision aspect can be seen in table 6 below:

Table 6. Level of job satisfaction in supervision aspects (Binned)

\begin{tabular}{|l|l|c|c|c|c|l|}
\hline \multicolumn{2}{|c|}{} & Frequency & Percent & $\begin{array}{c}\text { Valid } \\
\text { Percent }\end{array}$ & $\begin{array}{c}\text { Cumulative } \\
\text { Percent }\end{array}$ & Kriteria \\
\hline \multirow{4}{*}{ Valid } & $6.00-10.00$ & 2 & .9 & .9 & .9 & low \\
\cline { 2 - 7 } & $11.00-15.00$ & 2 & .9 & .9 & 1.9 & Middle \\
\cline { 2 - 7 } & $16.00-20.00$ & 18 & 8.3 & 8.3 & 10.2 & High \\
\cline { 2 - 7 } & $21.00-25.00$ & 194 & 89.8 & 89.8 & 100.0 & Very high \\
\cline { 2 - 7 } & Total & 216 & 100.0 & 100.0 & & \\
\hline
\end{tabular}

Table 6 shows that the teachers assessed the implementation of supervision both supervision by direct leadership and by the committee in Muhammadiyah DIY High School had been carried out well. Based on table 6, the level of teacher satisfaction on aspects of supervision has a dominant distribution in the very high category $(89.8 \%)$. The level of job satisfaction of teachers in the high category was $18.3 \%$, the level of job satisfaction of teachers in the medium category was $0.9 \%$, while those in the low category were as much as $0.9 \%$.

If described in the form of a pie chart, the conditions are as follows: 


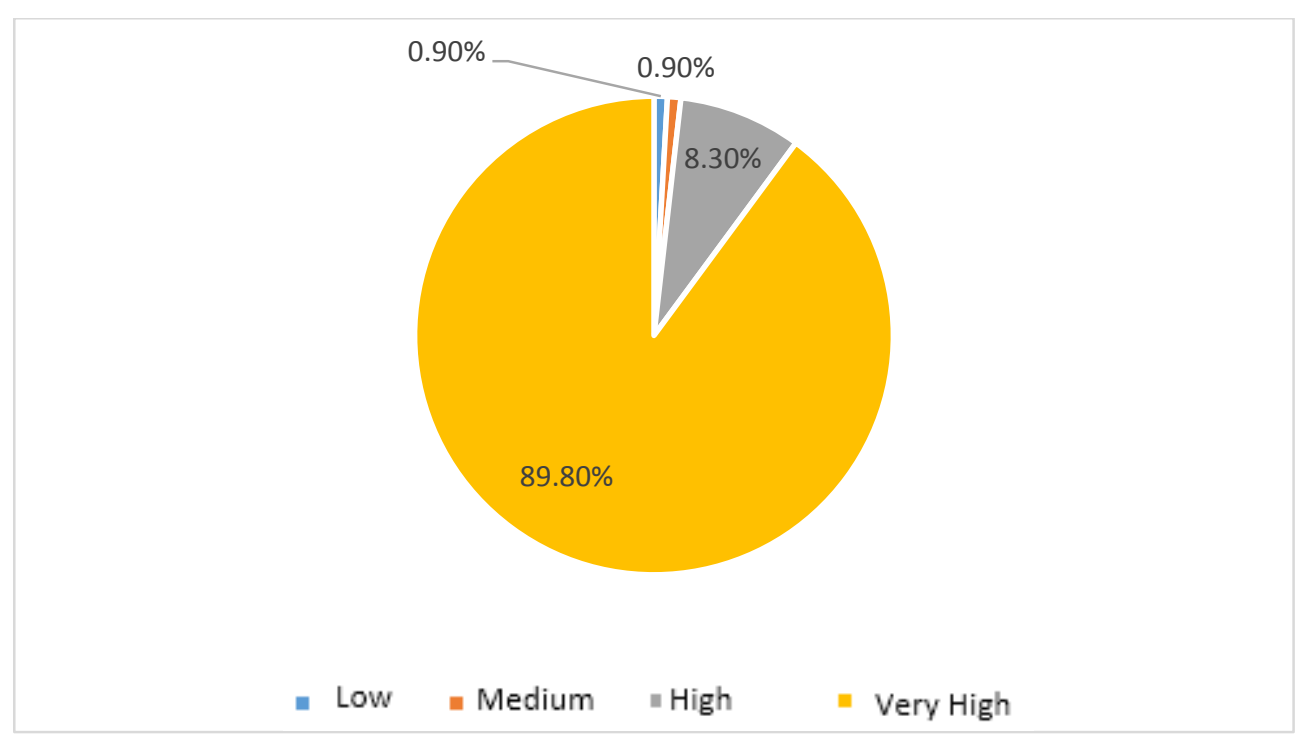

Figure 2. Level of job satisfaction of teachers in supervision aspects

The level of job satisfaction of teachers about promotion opportunities

Data on the level of teacher satisfaction in the aspect of promotion opportunities possessed by participants were obtained using a closed questionnaire. In the instrument, participants were asked about how participants viewed opportunities to get promotion opportunities for all teachers, promotion of the positions they got now, superior justice in providing promotional opportunities, and teacher comfort about promotional opportunities provided for participants as a Muhammadiyah teacher. Total questions about the level of satisfaction about the promotion opportunities that teachers have a number of 5 items, then the criteria for measuring the level of job satisfaction of teachers in terms of recognition of others is determined in table 7 .

Table 7. Criteria for the level of job satisfaction of teachers in promotion opportunities

\begin{tabular}{|l|l|}
\hline Values & Criteria \\
\hline $0-5$ & Very Low \\
\hline $6-10$ & Low \\
\hline $11-15$ & Medium \\
\hline $16-20$ & High \\
\hline $21-25$ & Very High \\
\hline
\end{tabular}

Statistically, the level of job satisfaction of Muhammadiyah DIY High School teachers in the aspect of promotion opportunities can be seen in table 8 below: 
Table 8. Statistics on the level of teachers job satisfaction about promotional opportunities

\begin{tabular}{|l|c|c|c|c|}
\hline & $\begin{array}{c}\text { All teachers at } \\
\text { my school, have } \\
\text { the same } \\
\text { promotion } \\
\text { opportunities }\end{array}$ & $\begin{array}{c}\text { I am } \\
\text { satisfied } \\
\text { with the } \\
\text { promotion } \\
\text { that I got } \\
\text { now }\end{array}$ & $\begin{array}{c}\text { The promotion } \\
\text { process and } \\
\text { procedures } \\
\text { used by my } \\
\text { supervisor are } \\
\text { fair }\end{array}$ & $\begin{array}{c}\text { I feel comfortable } \\
\text { with the } \\
\text { promotion } \\
\text { opportunities } \\
\text { available to me as } \\
\text { a teacher }\end{array}$ \\
\hline $\mathrm{N} \mid$ Valid & 216 & 216 & 216 & 216 \\
\cline { 2 - 6 } Missing & 0 & 0 & 0 & 0 \\
\hline Mean & 4.69 & 4.52 & 4.64 & 4.65 \\
\hline Median & 5.00 & 5.00 & 5.00 & 5.00 \\
\hline Mode & 5 & 5 & 5 & 5 \\
\hline
\end{tabular}

The distribution of teacher job satisfaction levels on the aspect of promotion opportunities can be seen in table 9 below:

Table 9. Teacher job satisfaction level aspect of promotion opportunities

\begin{tabular}{|l|l|c|c|c|c|l|}
\hline \multicolumn{2}{|c|}{} & Frequency & Percent & $\begin{array}{c}\text { Valid } \\
\text { Percent }\end{array}$ & $\begin{array}{c}\text { Cumulative } \\
\text { Percent }\end{array}$ & Criteria \\
\hline \multirow{4}{*}{ Valid } & $<=4.00$ & 1 & .5 & .5 & .5 & Low \\
\cline { 2 - 7 } & $9.00-12.00$ & 16 & 7.4 & 7.4 & 7.9 & Middle \\
\cline { 2 - 7 } & $13.00-16.00$ & 24 & 11.1 & 11.1 & 19.0 & High \\
\cline { 2 - 7 } & $17.00-20.00$ & 175 & 81.0 & 81.0 & 100.0 & Very high \\
\cline { 2 - 7 } & Total & 216 & 100.0 & 100.0 & & \\
\hline
\end{tabular}

Based on table 9, the level of teacher satisfaction on aspects of promotion oppor has a dominant distribution in the very high category $(81 \%)$. The level of job satisfaction of teachers in the high category was $11.1 \%$, the level of job satisfaction of teachers in the medium category was $7.4 \%$, while those in the low category were as much as $0.5 \%$.

The composition of job satisfaction levels of Muhamadiyah DIY high school teachers in the aspect of promotion opportunities can be seen in the following figure: 


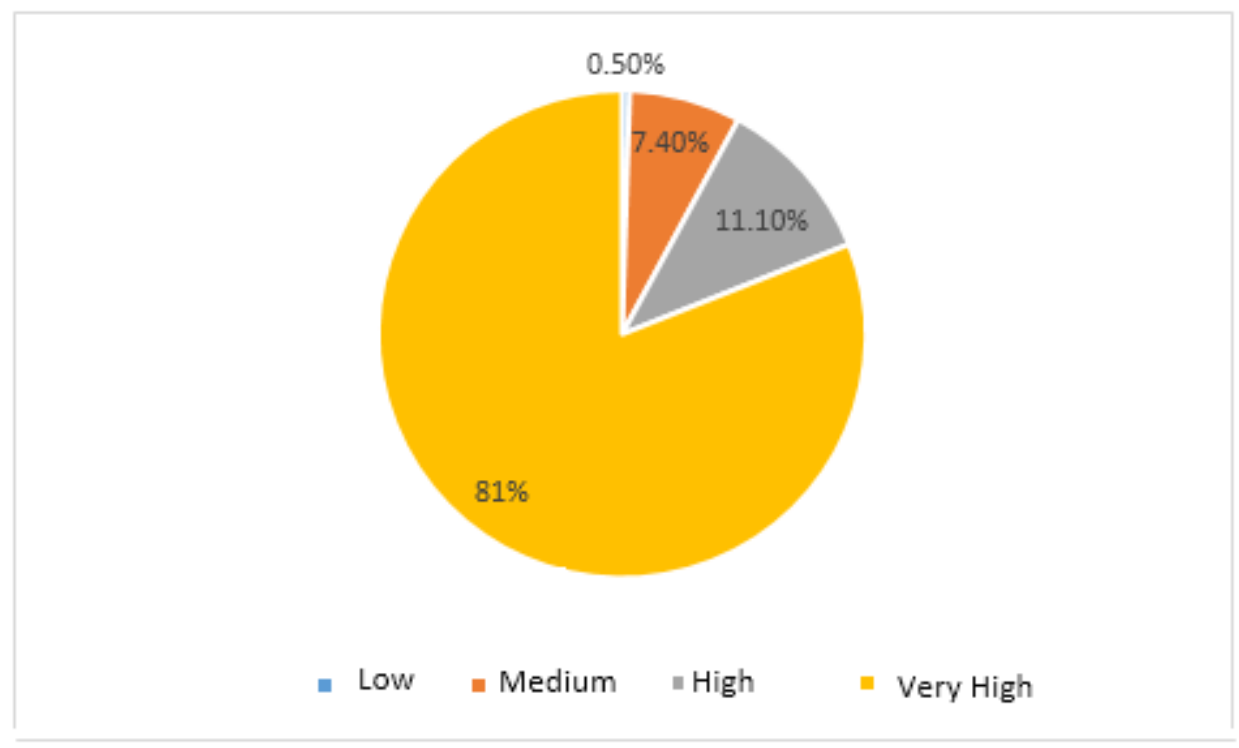

Figure 3. Level of job satisfaction teacher about promotion opportunities

This section discusses the results of research from various perspectives. In theory it is known that differences in the level of job satisfaction of teachers can be seen in terms of the difference between what is expected by someone and what is really obtained in the work environment. Hewstone and Stroebe (2001) define job satisfaction as an effective reaction to work that results from comparisons made by employees of actual and desired results. In this case, performance at work requires that a person's hopes and aspirations regarding consideration of appreciation and fulfillment of needs must be met. If these needs are met, employees will be satisfied with the work and greater satisfaction will generally motivate employees to perform their tasks more efficiently, thus resulting in increased organizational productivity. This is an important area of research because job satisfaction correlates with increased job performance, positive work values, high levels of employee motivation, and lower absenteeism, employee turnover and fatigue (Begley \& Czajka, 1993). Thus, measuring the level of teacher job satisfaction serves to find out what efforts can be made by school managers in order to significantly increase teacher job satisfaction by increasing student performance and learning.

There are two approaches available in the literature to conclude about the level of employee job satisfaction. The first is a normative approach in which a person's level of satisfaction is explained by means of comparing one's satisfaction with others in the sample; and the second approach is the absolute approach in which the numbers are determined by the researcher to represent dissatisfaction versus satisfaction. Therefore, given the job satisfaction questionnaire in this study using a 5-point Likert scale (strongly agree $=5$, Agree $=4$, Not sure $=3$, Disagree $=2$, and strongly disagree $=1$ ) we can assume that the agreement with the item positive words and disagreement with items with negative words will represent satisfaction, while disagreement with items with positive words; and agreement with negative words shows dissatisfaction. Therefore, the average score (after items with negative words are coded honorable) less than three represents' dissatisfaction '(slightly dissatisfied with very dissatisfied) while the average score above three is considered as' satisfaction '(a little satisfied with very satisfied).

The level of job satisfaction of teachers related to organizational policies is very important to study considering the policies issued by the direct leaders in the school or by the school organization manager is something that is directly related to the teacher and needs to get a 
positive response from the teacher to guarantee the implementation of the policy. An understanding of this issue was explored by knowing how participants viewed the organization policy including clarity of rules in schools, consistency in the implementation of the rules, the treatment of principals for all teachers equally, and how to lead conducted by principals that match the school conditions.

Based on table 23 it is known that the level of teacher satisfaction on aspects of organizational policy has a dominant distribution in the very high category $(79.6 \%)$. The level of job satisfaction of teachers in the high category was $16.7 \%$, the level of job satisfaction of teachers in the medium category was $3.2 \%$, while those in the low category were as much as $0.5 \%$. In this context, high and very high categories are defined as a condition that points to teacher satisfaction with these aspects. It can be concluded that organizationally, the Muhammadiyah organization has succeeded in producing organizational policies that can provide high job satisfaction for teachers.

In the supervision aspect, it is known that the majority of teachers have a very high level of job satisfaction $(89.8 \%$ ) in the supervision aspect, $8.3 \%$ are in the high category, $0.9 \%$ in the medium category, and $0.9 \%$ are in the low category. Thus the implementation of supervision in DIY Muhammadiyah High School has been carried out well. While in the promotion aspect it is known that teacher job satisfaction in the aspect of promotion opportunities is very diverse. There are $5 \%$ who have a low level of job satisfaction. As many as $7.4 \%$ of teachers have a moderate level of job satisfaction, $11.1 \%$ of teachers have a high level of job satisfaction, and $81 \%$ of teachers have a very high level of job satisfaction.

\section{CONCLUSION}

In general, the level of job satisfaction of Muhammadiyah high school teachers in Yogyakarta is at a high level both in the aspects of organizational policy, supervision, and promotion opportunities. That is a huge potential that Muhamamdiyah high school teachers in Yogyakarta have high organizational commitment. This refers to the results of the Tatar research (2020) that the level of job satisfaction of teachers has shown a very significant impact on the level of organizational commitment.

\section{REFERENCES}

Abbas, W. \& Asgar, I. 2010. The role of leadership in organisational change: Relating the successful organisational change to visionary and innovative leadership. Masters Thesis. University of Gavle.

American Psychological Association. (2017). APA ethical principles of psychologists and code of conduct. Retrived from https://www.apa.org/ethics/code/

Anastasiou, S. \& Papakonstantinou, Giorgos. (2014). Factors affecting job satisfaction, stress and work performance of secondary education teachers in Epirus, NW Greece. Int. J. of Management in Education. 8. 37 - 53. 10.1504/IJMIE.2014.058750.

Anderson, N. (2001). Organizational Psychology. London: Sage Publishers.

Azi, D.S. \& Augustine, A.S. 2016. Enhancing Job Satisfaction for Teachers: A Strategy for Achieving Transformation of Secondary Education in Nigeria. Journal of Education and Practice www.iiste.org ISSN 2222-1735 (Paper) ISSN 2222-288X (Online) Vol.7, No.13, 2016. Pp. 37-41.

Baluyos, Genelyn \& Rivera, Helen \& Baluyos, Esther. (2019). Teachers' Job Satisfaction and Work Performance. Open Journal of Social Sciences. 07. 206-221. 10.4236/jss.2019.78015. 
Bratianu, C. (2015). Organizational Knowledge Dynamics: Managing Knowledge Creation, Acquisition, Sharing, and Transformation. Hershey: IGI Global. DOI: 10.4018/978-14666-8318-1.ch012.

Buitendach, Joey \& De Witte, Hans. (2005). Job insecurity, extrinsic and intrinsic job satisfaction and affective organisational commitment of maintenance workers in a parastatal. South African Journal of Business Management. 36. 10.4102/sajbm.v36i2.625.

Chu, E. H. S. 2007. Building trust in elementary schools: The impact of home school community collaboration. International Journal about Parents in Education 1 (0), 08-20

Cockcroft, J. (2001). Job satisfaction and organizational commitment: An empirical investigation in the Free State branches of a service organization. Unpublished honours thesis, University of the Free State, Free State.

Collie, R. J., Shapka, J. D., \& Perry, N. E. (2012). School Climate and Social-Emotional Learning: Predicting Teacher Stress, Job Satisfaction, and Teaching Efficacy. Journal of Educational Psychology, 104, 1189-1204. http://dx.doi.org/10.1037/a0029356.

Demirtaş, Zülfü. (2010). Teachers' job satisfaction levels. Procedia - Social and Behavioral Sciences. 9. 1069-1073. 10.1016/j.sbspro.2010.12.287.

Essays, UK. (November 2018). The concept and definition of job satisfaction. Retrieved from https://www.ukessays.com/essays/psychology/the-concept-and-definition-of-jobsatisfaction-psychology-essay.php?vref $=1$

Griva, E., Panitsidou, E., \& Chostelidou, D. (2012). Identifying factors of job motivation and satisfaction of foreign language teachers: Research project design. $\%$ E2\%80\%8BProcedia-Social and Behavioral Sciences, 46, 543-547. http://dx.doi.org/10.1016/j.sbspro.2012.05.157

Hasanah, E. (2012). Identitas profesional guru ips smp pascasertifikasi di kabupaten sleman. S2 thesis, UNY.

Hasanah, E. (2019). Perkembangan moral anak SD berdasarkan teori Kohlberg. JIPSINDO $6(2), 131-145$

Hasanah, E. (2012). Menanamkan Jiwa Kepemimpinan Melalui Metode Update Status Dalam Pembelajaran Ekonomi Di SMA NEGERI I DEPOK. Prosiding Seminar Nasional DPP IKA UNY.

Hasanah, E. (2014). Peran MGMP dalam meningkatkan profesionalisme guru IPS. Prosiding seminar nasional, DPP IKA UNY,

Hasanah, E. (2016). Interaksi guru siswa yang efektif. Prosiding seminar nasional Dies Natalis UNY, DPP IKA UNY.

Hasanah, E., Zamroni, Dardiri, A., Setyabudi, I., \& Supardi. (2018). Literature review of parenting style to support the development of adolescent identity. Asian Social Science, 51114(6), 1911-2025. https://doi.org/10.5539/ass.v14n6p157

Hasanah, E., Zamroni, Z., Dardiri, A., \& Supardi, S. (2019). Indonesian adolescents experience of parenting processes that positively impacted youth identity. The Qualitative Report, 24(3), 499-512. Retrieved from https://nsuworks.nova.edu/tqr/vol24/iss3/5

Inuwa, Mohammed. (2015). The Impact of Job Satisfaction, Job Attitude and Equity on Employee Performance. The International Journal Of Business \& Management (ISSN 2321 -8916). 3. 288-293.

Karakus, M. and Savas, A. C. (2012) The effects of parental involvement, trust in parents, trust in students and pupil control ideology on conflict management strategies of early childhood teachers. Educational Sciences: Theory and Practice, 12(4), 2977-2985.

KNigama, Selvabaskar, S., \& Surulivel, S.T. 2018. Job Satisfaction Among School Teachers. International Journal of Pure and Applied Mathematics. Volume 119 No. 7 
2018, 2645-2655 ISSN: 1311-8080 (printed version); ISSN: 1314-3395 (on-line version) url: http://www.ijpam.eu Special Issue.

Kosteas, Vasilios. (2010). Job Satisfaction and Promotions. Industrial Relations: A Journal of Economy and Society. 50. 174 - 194. 10.1111/j.1468-232X.2010.00630.x.

Kreitner, Kinicki. 2010. Organizational Behavior. New York: McGraw-Hill

Locke, E. (1976). The nature and causes of job satisfaction, In Dunnette, M. D. (Ed.), Hand book of I/O Psychology. Chicago: Rand-McNally

Luhn, André. (2016). The Learning Organization. Creative and Knowledge Society. 6. 1-13. 10.1515/cks-2016-0005. De Gruyter.

Malik, Muhammad \& Danish, Rizwan \& Munir, Yasin. (2012). The Impact of Pay and Promotion on Job Satisfaction: Evidence from Higher Education Institutes of Pakistan. American Journal of Economics. 2. 6-9. 10.5923/j.economics.20120001.02.

Ram P (2013). Relationship between Job Satisfaction and Job Performance in the Public Sector- A Case Study from India. International Journal of Academic Research in Economics and Management Sciences, 2(2).

Robbins, S.P. (1998). Organisational behavior.(8th ed.). New Jersey: Prentice Hall.

Sarwar. A. \& Khalid, A.(2011). Impact of employee empowerment on employee's job satisfaction and commitment with the organization. Interdisciplinary journal of contemporary research in business. 3(2): 664-683.

Shajahan, D. S. \& Shajahan, L. (2004).Organization behaviour. New Age International Publications.

Spector, P. E. (1985). Measurement of human service staff satisfaction. American Journal of Community Psychology, 13 (6), 693-711

Tatar, A. (2020). Impact of Job Satisfaction on Organizational Commitment. Lambert Academic Publishing. ISBN: 978-620-0-48272-3

Tentama, F. (2015). Peran Kepuasan Kerja Terhadap Kinerja Pada Guru Pegawai Negeri Sipil (PNS) di Yogyakarta. Jurnal Psikologi Undip. 14. 10.14710/jpu.14.1.1-8.

Wagner L and Ruch W. 2015. Good character at school: positiveclassroom behavior mediates the linkbetween character strengthsand school achievement.Front. Psychol. 6:610. 